\title{
Demystifying entrepreneurship and innovation to prepare Generation $Z$ for possibilities of self-employment
}

\author{
Dr Vusumuzi Malele \\ Department of Industrial Engineering, Engineering and Built Environment, Pretoria, South Africa \\ vusimalele@gmail.com
}

\begin{abstract}
A need for a better living and the lack of jobs are real-world problems which affects the generation Z. Innovation and entrepreneurship is an important socio-economic factor that could create jobs. Using the mixed-methods, this paper shares the findings of a doctoral research project aimed at exploring and testing how students in Engineering and Technology Education classes perceive the inclusion of Entrepreneurship and Innovation Education concepts in their modules. The exercise took place from 2013 to 2016. The paper highlights a UniversitySponsored Student Business Venture model which was used to train students; while its inclusion in the Network System module, resulted in students proposing innovative ideas that needed prototype or product development funding. This exercise showed students how inclusion of entrepreneurship and innovation could lead to skills that could profitably help them explore ideas for purpose of establishing self-employment through student-led new business ventures.
\end{abstract}

Keywords: generation Z, entrepreneurship and innovation, student entrepreneurs and innovators, university-sponsored business venture, joint ventures

\section{Dr Vusumuzi Malele}

Department of Industrial Engineering, Engineering and Built Environment, Pretoria, South Africa vusimalele@gmail.com

\section{Introduction}

Solutions aimed at addressing youth unemployment require different strategies, processes, frameworks and models. One such a solution would be to demystify and include entrepreneurship and innovation education (EIE) in the mainstream engineering and technology education (ETE). The aim of EIE in ETE will be to provide students will knowledge that could eventual lead them to create their own student-led business ventures or start-ups.

Due to the need for economic growth, the importance of EIE has traverse different areas of study; for example, as much as EIE was offered in business-, economic-, accounting- and managementsciences (Van der Lingen, and Van Niekerk 2015), it is now key in natural and applied science.

Malele, Mpofu and Muchie (2016) sees EIE and ETE as mutually exclusive areas since they describe the EIE environment as the one that supports a nonlecturer dominated learning environment and provides students with the opportunity to be creative and innovative. While the instructor receives an opportunity to evaluate if students have mastered skills, concepts and other competencies needed to solve problems.

In ETE, students learn to solve problems that involve complex systems which require many skills, concepts and other competencies (Schunn and Silk 
2011). While, EIE is a teaching and learning practice in which principles, concepts, and theories of entrepreneurship and innovation are taught to students. EIE increases the chances of start-ups and self-employment and perhaps enhances individuals' economic satisfaction. Good preparation increases the chance of success.

Against this backdrop, this paper shares the findings of a doctoral study that investigated the inclusion of EIE concepts in ETE setting from 2013 to 2016. The latter was conducted to prepare and enable students from 15 to 24 years of age (better known as Generation Z) with skills and capabilities of creating their own new ventures. In this regard, using a pragmatic research approach, a practise of altering the existing ETE curriculum is presented and the lesson(s)-learned is reported as findings and recommendations of this paper. The paper contributes by fostering an idea that the entrepreneurship and innovation chasm could be bridged through the inclusion of EIE in the existing mainstream curriculum.

The sections below will present the papers hypothesis as guiding principle, briefly define what is meant by Generation Z, briefly discuss EIE in ETE, and conclude by presenting the adopted methodology, the findings, and recommendations.

\section{Hypothesis}

This paper's hypothetical viewpoint is that it is possible to entrepreneurship and innovation could be demystified, and then used to teach (Computer Systems Engineering) students techniques of establishing new ventures without affecting their ETE curriculum. The hypothesis was explored and tested from 2013 to 2016 at one of the South African UoTs. In conducting the latter exercise, a UniversitySponsored Student Business Venture (USSBV) model (Malele, et. al., 2017a) was introduced as the necessary business model, to explicitly indicate the process of how students could be assisted to use and exploit their ideas into living organizations.

\section{Generation Z: Defined and Described}

According to Fernández-Cruz and FernándezDíaz (2016) Generation $Z$ is sometimes called Generation V (for virtual), Generation C (for community or content), the Silent Generation, or the Internet Generation. Generation $\mathrm{Z}$ was born into a different technological world during the conception and birth of the World Wide Web (www) than their predecessors Generation Y (Geck, 2007). There is no agreement in describing the year in which Generation $\mathrm{Z}$ was born. However, literature has been consistent that the term Generation $\mathrm{Z}$ is used to describe those individuals that were born in the 1990s (Geck, 2007; Schroer, 2008, Rozenberga and Paidere, 2015; Fernández-Cruz and Fernández-Díaz, 2016). For example, Rozenberga and Paidere (2015) posits that Generation $\mathrm{Z}$ were born in the period of 1990s to the early 2000s; Schroer (2008) said they were born between 1995 and 2012; Fernández-Cruz and Fernández-Díaz (2016) have identified and divided generation $\mathrm{Z}$ into generation $\mathrm{Z1}$, born between late 1990 and 2000, and the generation Z2, those born after 2005. Subsequent to Generation $Z$ as illustrated in Figure 1, Generation $\alpha$ (also known as Google Kids) has been proposed as those born after 2010 to 2025 . They are seen as the first generation of the 21st century who will have and exceed the factors of Generation Z. See Figure 1 for the diagrammatically description.

Regardless of their age or name prescription, there are common factors that better define generation $\mathrm{Z}$. They have (i) good skills in information and communication technologies (ICTs); (ii) good electronic multitaskers, while snacking and watching television; (iii) heightened technical expectations, attitudes, and beliefs; (iv) fast and impatient; (v) socially open through the use of technologies; and (vi) strong interest in their financial stability, (Geck, 2007; Fernández-Cruz and Fernández-Díaz, 2016).

In 2019, Generation $Z$ were those individuals in ages 14 to 24 years old. The majority of school learners in South Africa, complete their secondary education either at 17 or 18 years of age. Then they enrol either at the university or college for their tertiary education which they complete their three year qualification around 21 years and second qualification around 24 years (depending on the number of years they spent). These individuals are students and are faced with different challenges than their predecessors (Generation Y), among which could be a need for employment and better living.

This paper postulate that possibilities of selfemployment among students could increase if entrepreneurship and innovation could be demystified and be inculcated as a teaching and learning activity in the students' curriculum without them enrolling for an 


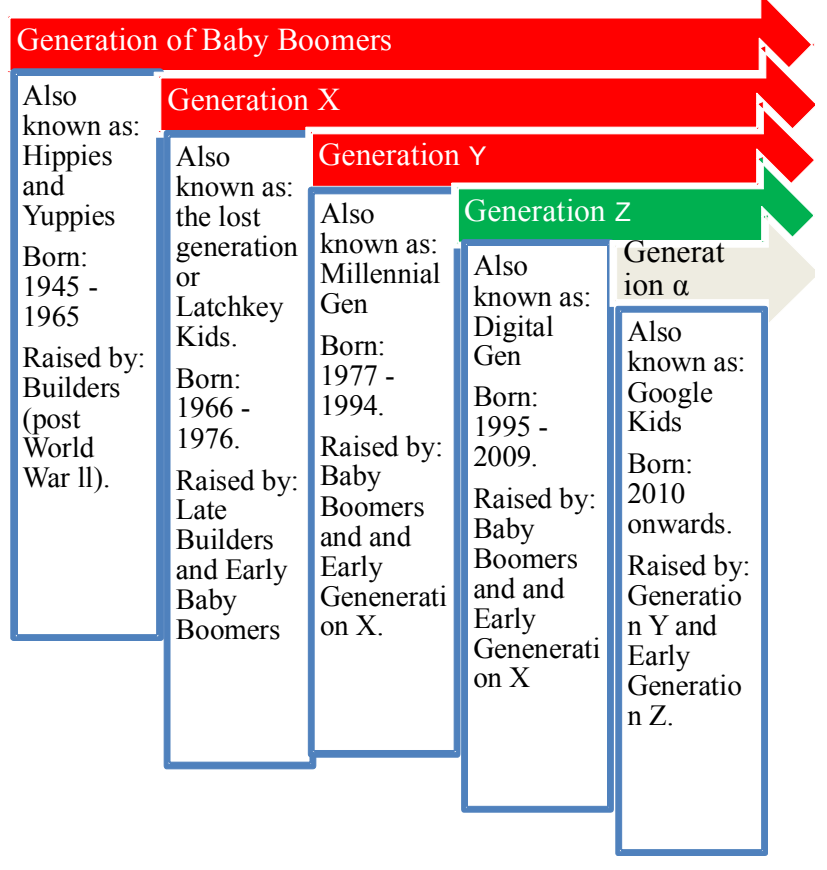

Fig. 1: Different types of Generations as of Baby Boomers (Source: Authors adaptation).

EIE course. In this regard, the following section will briefly discuss the role and importance of EIE.

\section{Entrepreneurship and Innovation Education}

Entrepreneurship and Innovation are terms with different meanings but have a relationship which sometimes creates confusion (Entrepreneur Africa Magazine, 2017). The key difference between innovation and entrepreneurship is on their general view. For example, innovation means introducing something new which is an idea, product, model, or a service, and entrepreneurship means making or exploiting an innovation into a business opportunity (Malele, 2019).

Entrepreneurship and innovation describe the efforts of using new and existing ideas to establish new businesses. Entrepreneurship and innovation uses the individuals who exploit entrepreneurial opportunities. In a university context, among others, these individuals are students. Students' creativity is the tool for innovation, while innovation is a tool for entrepreneurship (Malele, Mpofu, and Muchie, 2017a).

Timmons, Zacharakis, and Spinelli (2004) mention that entrepreneurship and innovation are guided by three key factors: (i) the team, (ii) the opportunity, and (iii) the resources. The establishment of the new venture take place when the latter factors are combined. Students (Generation Z) are a good group of individuals that could form entrepreneurial and innovation teams. When they are placed in opportunity ready environments such as universities, they a business modelling tool that could either to be entrepreneurial and innovative in mind.

Inclusion of Entrepreneurship and Innovation Education in Engineering and Technology Education

There is a need for a new educational approach that will provide Engineering and Technology Education (ETE) students with a potential of using their motivation, ideas and knowledge to formulate new innovative ventures. In general, the inclusion of EIE in ETE, mixes the basic technical knowledge with essential for entrepreneurship and innovation topics to equip and make the students to be ready for establishing ventures. The inclusion, at the undergraduate level, allows the students to understand the basics of entrepreneurship and innovation throughout their formative years of their engineering education; while, at the graduate level, it is made a choice for the students (Wilson, Holloway, Cox, and Goldstein, 2014)

The rationale of including EIE in ETE is informed by the following:

- The Venturewell (2016) identified five trends that will shape EIE, namely: (i) deeper integration, (ii) more inclusion, (iii) make spaces as the new normal, (iv) new language for getting out of the classroom, (iv) global passion sparks global solutions. The deeper integration refers to integrating EIE throughout the university curriculum, weaving it into the fabric of higher education in particular ETE areas. This is because engineering brings ideas to life that would be to say every ETE should involve some form of creativity that solves socio-economic challenges.

- ETE curriculum needs regular maintenance (ABET, 2018) which modernize it, allow it to relate and link with other curricula such as that of EIE. In this regard, curriculum maintenance could allow academics to be aware of entrepreneurial and innovative activities that help students to exploit ideas into new ventures. Such curriculum could properly balance theory and its practice (Cristina, 2016). 
- ETE requires the application of different transferable competencies.

In implementing EIE, Wilson, et. al. (2014) point to the fact that entrepreneurship and innovation courses are already offered as minor modules or through certification. However, the latter is good for starting new EIE programmes but for establishing new ventures EIE concepts should be introduced to existing curriculum.

Table 1 below illustrates different EIE classifications of teaching and learning methods, approaches, and pedagogies that could be practised in ETE. Some of the teaching methods in Table 1 could be combined to effectively provide students with the best learning methods.

The project-based teaching and experiential learning methodology employ problem-solving teaching-learning strategy which comprise of the following stages (Enikő, 2013): (i) creation of a problematic situation; (ii) analysis and synthesis of the problem; (iii) the definition of the key problem question, (iv) construction of the problem solving plan; (v) recognition of the unknown in the problem; (vi) execution of the corrections arising during the process of problem solving; (vii) synthesis of the information obtained from the parts of the problem; (viii) answering of the key problem question; and (ix) outlining of the new problem.

Project-based teaching that leads to experiential learning seemed to be more effective and mostly

Table 1: Summary of the EIE Teaching and Learning Methods (Source: Wilson, et. al., 2014).

\begin{tabular}{|l|l|}
\hline Teaching Method & Learning Method \\
\hline Case Studies & Experiential Learning \\
\hline Writing Business Plans & Experiential Learning \\
\hline $\begin{array}{l}\text { Lectures by Business } \\
\text { Owners or } \\
\text { Entrepreneurs }\end{array}$ & Didactic Learning \\
\hline Traditional Lecture & Didactic Learning \\
\hline Computer Simulation & Experiential Learning \\
\hline Student Clubs & $\begin{array}{l}\text { Pseudo-Experiential } \\
\text { Learning }\end{array}$ \\
\hline Project-based & (Pseudo-) Experiential Learning \\
\hline Internships & Experiential Learning \\
\hline $\begin{array}{l}\text { Model-Eliciting } \\
\text { Activities (MEAs) }\end{array}$ & Experiential Learning \\
\hline
\end{tabular}

applied in ETE. For example, Soares, Sepúlveda, Monteiro, Lima, and Dinis-Carvalho (2013) used the project-based teaching-learning methodology to facilitate the Innovation and Entrepreneurship Integrated Project (IEIP) based at the School of Engineering, University of Minho. In the IEIP, to facilitate four groups of 4th level ETE students to compete against each other in developing or improving commercial products manufactured by actual industries.

Unfortunately, Soares, et al. (2013) did not mention how they enhanced students' didactic learning. This is limiting because as Enikő (2013) mentioned that the didactic strategy employed by the instructor could lead to the successful teaching and learning. Furthermore, students' experiential learning needed by entrepreneurs and innovators was not enhanced. For example, Okudan and Rzasa (2006) allowed students to write business plans focusing on product innovation and improvement this could develop their entrepreneurship skills but poses the limitation in the innovation skills such as ideation (idea generation). While Soares, et al., (2013) choose five innovative products that were already developed so that students' could work-on enhancing them. The latter could develop students' innovative skills but placing limitations on their entrepreneurship skills.

The above disadvantages show that there is a need for a teaching and learning methodology that could employ problem-solving methodology while improving entrepreneurship and innovation skills. Such a teaching and learning methodology could be a Modeling teaching and learning strategy (Enikö, 2013) because it employs problem-solving techniques as it allows the students to progress through the process of learning from new, unknown information with the aid of the existing reality constructs to devise the new world model constructs.

Malele, et al., (2017b) postulates that the inclusion of ideation-to-exploitation process is a key EIE component that has been left out from the current ETE curriculum. They developed and propose such a process and call it the USSBV (Malele, et al., 2017a). Such a process is important for students as it is an enabler for establishing new ventures.

The following section will discuss the adopted research methodology through a lens of a case study setting in which EIE concepts, in particular the USSBV, were included in the ETE course. 


\section{Methodology}

Research Method and Setting

This paper adopted a pragmatic approach to research (Alzheimer-Europe 2009; Glasgow 2013). The pragmatic approach to science provide researchers with a freedom to use (in combination/mixed or as individual) any of the methods, techniques, and procedures best suited for the research problem. In this regard, in agreement with Creswell (2014), pragmatism opens the door to multiple methods, different worldviews, and different assumptions, as well as different forms of data collection and analysis.

Mixed methods involve combining or integration of qualitative (i.e. data that tends to be open-ended without predetermined responses) and quantitative (i.e. data that usually includes closed-ended responses) research (Alzheimer-Europe 2009; Glasgow 2013; Creswell, 2014). The major reason for using mixed methods resonate with the fact that with respect to data collection, all methods have biases and weaknesses; however, the use of both quantitative and qualitative data balance biaseness and neutralize the weaknesses of each form of data (Creswell, 2014).

There are several typologies for classifying and identifying types of mixed methods strategies (see Creswell, 2009; Teddlie, and Tashakkori, 2009; Morgan, 2013; Creswell 2014). The Convergent Parallel Mixed Methods (CPMM) was relevant in conducting this work because it allowed the researcher to collect both quantitative and qualitative data, analyzes the data separately, and then compare the results to see if the findings confirm or disconfirm each other (Creswell 2014).

This study used the CPMM approach to implemente a case study in which EIE concepts were included in the ETE curriculum from 2013 to 2016.

The setting for the case study was a Computer Systems Engineering (CSE) course, Network Systems IV (NSY401T), which was used to train students on wireless and mobile communication theories, principles and techniques. The NSY401T was offered to Bachelor of Technology (BTech) degree students at a UoT in South Africa. Tests, oral/written assignments and a written examination were used to assess the NSY401T.
Data sample

A sample data for this paper was drawn from a group of 101 students befitting the Generation $\mathrm{Z}$ age profile (see Table 2). Of the 101 students, 28 were registered in 2013, 23 (2014), 20 (2015) and 30 (2016).

Table 2: Summary of the demographics of NSY401T students from 2013 to 2016.

\begin{tabular}{|l|l|l|l|l|l|}
\hline \multirow{2}{*}{ Age } & \multirow{2}{*}{ Gender } & \multicolumn{4}{|l}{ No. of Years } \\
\cline { 3 - 6 } & & $\mathbf{2 0 1 3}$ & $\mathbf{2 0 1 4}$ & $\mathbf{2 0 1 5}$ & $\mathbf{2 0 1 6}$ \\
\hline \multirow{2}{*}{20 to 23} & Male & 15 & 12 & 11 & 15 \\
\cline { 2 - 6 } & Female & 13 & 11 & 9 & 15 \\
\hline \multicolumn{2}{|l}{ No. of Groups } & 5 & 5 & 4 & 6 \\
\hline
\end{tabular}

\section{Findings}

\section{Pilot Study}

In 2013, a preliminary study was conducted in which 28 NSY401T students were tasked with the assignment of searching for entrepreneurship and innovation ideas that could address the socioeconomic challenges.

The students' ideas were assessed for relevance and possibility of exploiting them into the establishment of some businesses. During and after the process of evaluating the entrepreneurship and innovation ideas that emanated from the assignment, the instructor asked the students three preliminary research questions:

(i) Are you or would you be keen to become an entrepreneur and/or an innovation actor?

This question was asked before and after students embark on their assignments. The results (illustrated in Figures $2 a$ and $b$ ) revealed that majority of students, about $43 \%$ (before they were exposed to the task of conducting the assignment) were not keen to become entrepreneurs and/or innovation actors. While, after conducting the assignment, the number of those interested to become entrepreneurs and/or innovation actors increases from $39 \%$ to $68 \%$; with those not keen to become entrepreneurs and/or innovation actors reduced to entrepreneurs and/or innovation actors and those not sure reduced to $11 \%$.

Figure 2a and 2b: The 2013 students' interest in becoming an entrepreneur and/or innovation actor. 


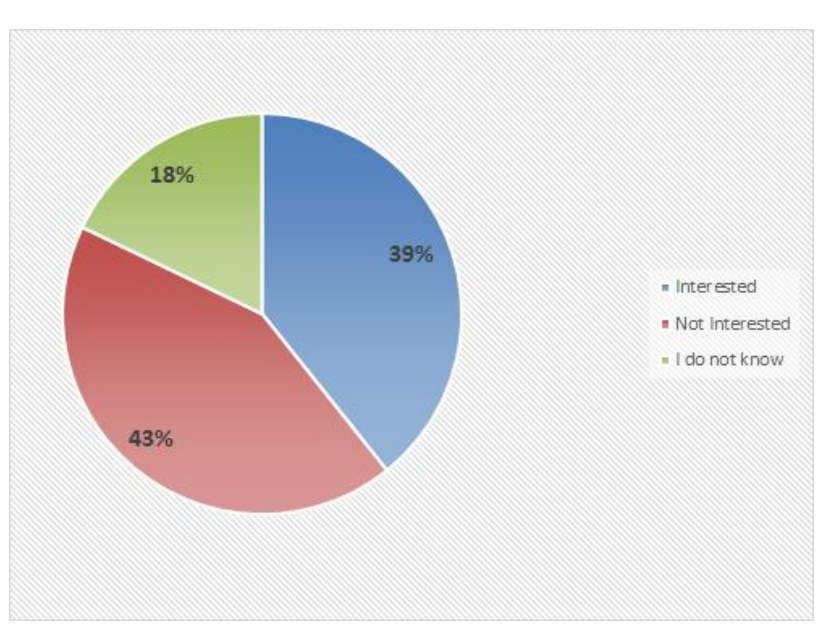

Before

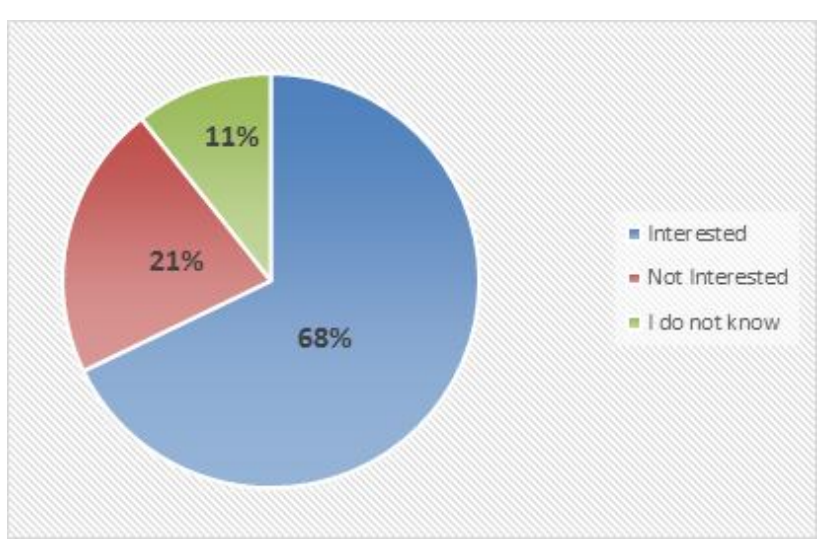

After

The following is an extract from interviews that were conducted with the different student groups before and after they could conduct their assignment:

The quantitative analysis in Figure 2 and qualitative analysis in Table 3 illustrate a fact that after students conducted the entrepreneurship and innovation assignment, the number of students keen to become entrepreneurs and/or innovation actors increased.

Table 3: Answers from interacting with the students about entrepreneurship and innovation.

\begin{tabular}{|c|l|}
\hline \multicolumn{2}{|c|}{$\begin{array}{c}\text { Do you think entrepreneurship and innovation is your group } \\
\text { thing? Briefly explain your answer. }\end{array}$} \\
\hline $\begin{array}{c}\text { Before } \\
\text { (1) }\end{array}$ & $\begin{array}{l}\text { No. We feel we need training that can lead us to } \\
\text { entrepreneurship and innovation. }\end{array}$ \\
\hline $\begin{array}{c}\text { After } \\
(2)\end{array}$ & $\begin{array}{l}\text { Yes. The entrepreneurship and innovation } \\
\text { activities are good training process that } \\
\text { interest to become entrepreneurs and/or } \\
\text { innovators. }\end{array}$ \\
\hline $\begin{array}{c}\text { Before } \\
\text { (2) }\end{array}$ & $\begin{array}{l}\text { Yes. Majority of group members participated in } \\
\text { entrepreneurship and innovation activities. }\end{array}$ \\
\hline
\end{tabular}

\begin{tabular}{|c|l|}
\hline $\begin{array}{c}\text { After } \\
\text { (2) }\end{array}$ & $\begin{array}{l}\text { Yes. The assignment gave more interest to become } \\
\text { entrepreneurs and/or innovators; it should be } \\
\text { allocated enough time for us to build prototypes } \\
\text { and market them to potential clients. Hence, other } \\
\text { skills such as marketing are vital. }\end{array}$ \\
\hline $\begin{array}{c}\text { Before } \\
\text { (3) }\end{array}$ & No. None of us feels that business is their thing. \\
\hline $\begin{array}{c}\text { After } \\
\text { (3) }\end{array}$ & $\begin{array}{l}\text { Yes. This assignment made us real ise that } \\
\text { everyone could become entrepreneurship and/or } \\
\text { innovation. }\end{array}$ \\
\hline $\begin{array}{c}\text { Before } \\
\text { (4) }\end{array}$ & $\begin{array}{l}\text { No. We definitely need more experience to be } \\
\text { entrepreneurs. }\end{array}$ \\
\hline $\begin{array}{c}\text { After } \\
\text { (4) }\end{array}$ & $\begin{array}{l}\text { Yes. The assignment gave us some deeper } \\
\text { understanding of the process. }\end{array}$ \\
\hline $\begin{array}{c}\text { Before } \\
\text { (5) }\end{array}$ & No. None of us sees is passionate about it. \\
\hline $\begin{array}{c}\text { After } \\
\text { (5) }\end{array}$ & $\begin{array}{l}\text { Yes. The assignment provided us with } \\
\text { understanding and rose a passion for } \\
\text { entrepreneurship and innovation. }\end{array}$ \\
\hline
\end{tabular}

(i) Is there a need for a guiding framework for conducting the assignment?

Students were asked this question twice in a year, after 8 weeks of starting the course and on the day of conducting final assessments. Generally, the majority of students, 23 of $28(82 \%)$ thought that there was a need for a guiding framework that would aid them to embark on their assignment (see Figure 3 ).

The following is an extract from interviews that were conducted with the different student groups:

The course instructor: "Out of all the challenges that you have come across during the time you undertook this assignment; could you please mention at least one thing that you could raise as your major challenge."

Group 1: "Lack of teamwork was a big challenge..."

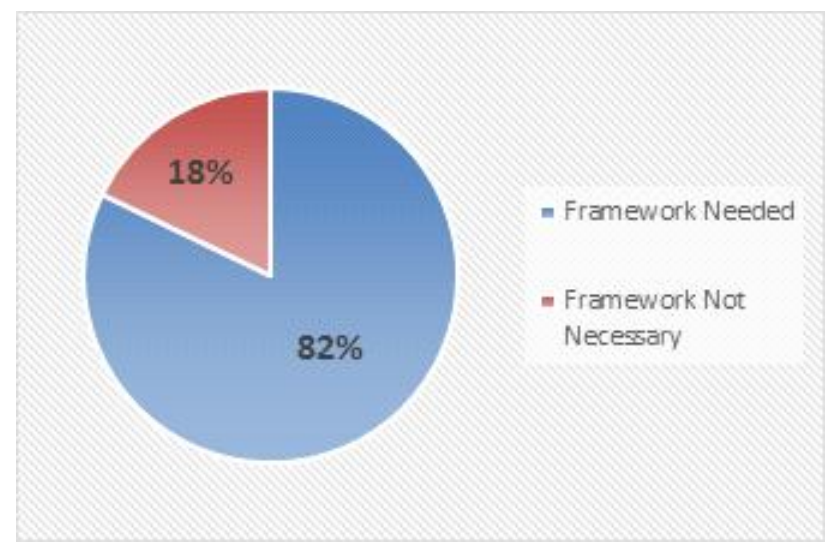

Fig. 3: Responses to the need for an assignment guiding framework. 
Group 2: "Lack of rules that could guide us in conducting the assignment was a challenge..."

Group 3: "A challenge was there were no clear methods for conducting the assignment..."

Group 4: "Clarity of rules of engagement for conducting the assignment was a challenge..."

Group 5: "There is a need for rules that could guide us in conducting the assignment..."

Figure 3 and interview extract corroborate the fact that students required an assignment framework to conduct entrepreneurship and innovation activities.

(i) Was it easy to identify the entrepreneurship and innovation ideas that could address the socioeconomic challenges? How have you conducted the exercise of identifying the ideas? Was the assignment eye-opening?

These questions were asked on the final day of the assignment assessment. Figures $4 \mathrm{a}, \mathrm{b}$, and c illustrate the fact that majority of the students felt that it was easy to identify the project and they source the ideas from problems faced by students, lecturers, and the communities closer to the university. Furthermore, they believed that engaging in this assignment was an eye-opening exercise in terms of available entrepreneurship and innovation opportunities/ideas for addressing community challenges and also possibilities of exploiting those ideas into establishing new business ventures. The major source of ideas appeared to be communities in the vicinity of the university.

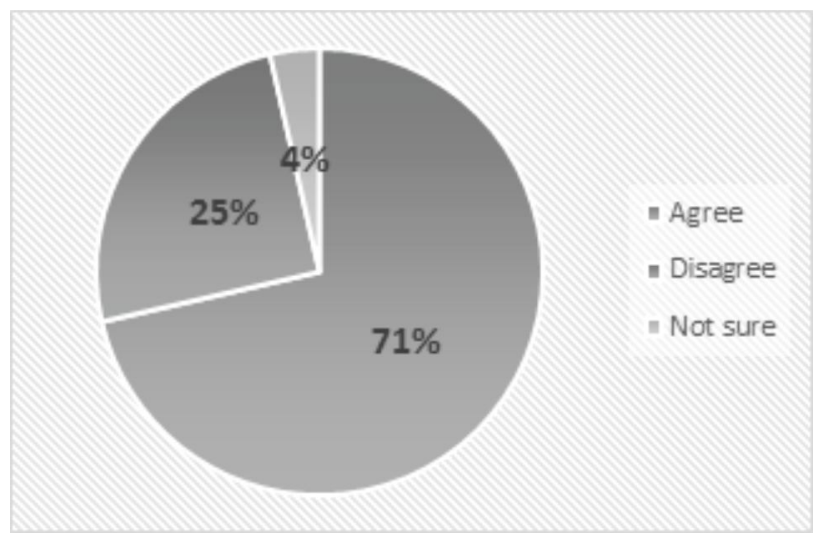

Fig. 4a: Responses for easiness of sourcing entrepreneurship and innovation ideas

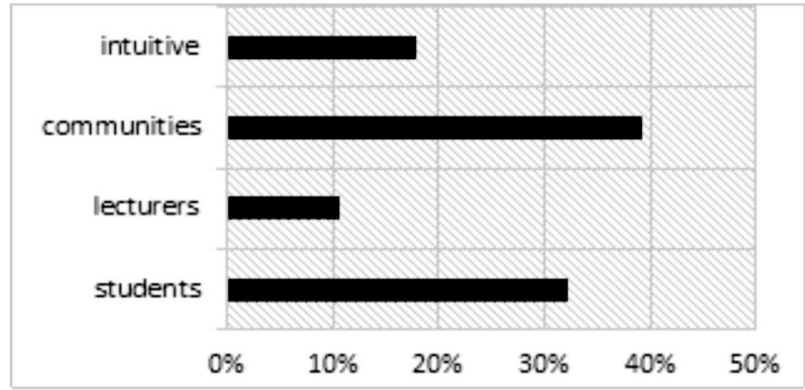

Fig. 4b: Sources of entrepreneurship and innovation ideas.

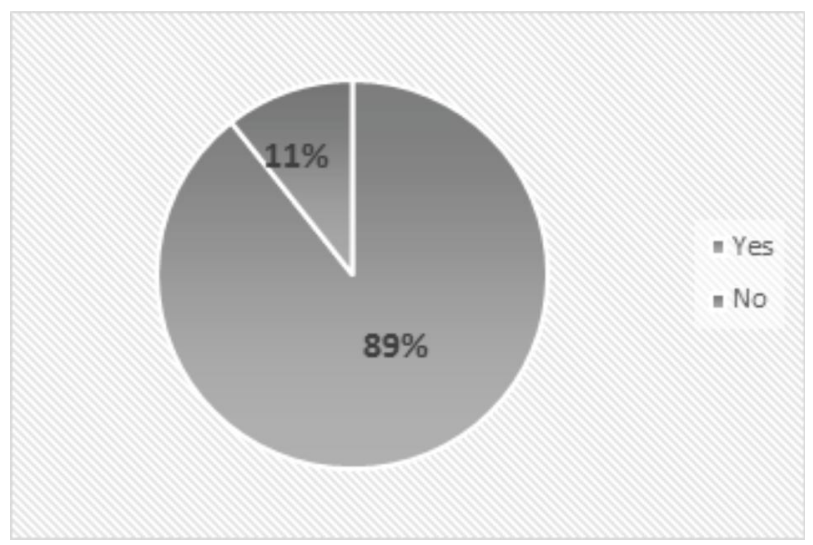

Fig. 4c: The assignment was eye-opening.

The following is an extract from interviews that were conducted with the different student groups. The interview questions were phrased as follows:

Q1. Was it easy to identify the entrepreneurship and innovation ideas geared at addressing social and economic challenges?

Q2. How have you conducted the exercise of identifying the ideas?

Q3. Was the assignment eye-opening?

As illustrated in Figure 4 and Table 4, the ideas from the entrepreneurship and innovation activities mostly came from the community (i.e. students and people in local townships), and it concurs that such activities create and improve students' entrepreneurship and innovation flair.

\section{Actual Study}

Learning from the lessons of the pilot study conducted in 2013, in particular, the fact that students mentioned their existence of a need for a guiding framework for the assignment; then, in 2014, 23 students grouped into five groups were requested to work on a similar assignment task that will suggest 
Table 4: Answers from interacting with the five groups (Gp) of students about gathering the entrepreneurship and innovation

\begin{tabular}{|c|c|c|c|}
\hline Gp & Q1 & Q2 & Q3 \\
\hline 1 & Yes & $\begin{array}{l}\text { We did } \\
\text { brainstorming } \\
\text { exercises }\end{array}$ & $\begin{array}{l}\text { Indeed, we learnt that } \\
\text { there were a lot of } \\
\text { challenges that needed } \\
\text { to be resolved. }\end{array}$ \\
\hline 2 & Yes & $\begin{array}{l}\text { We divided } \\
\text { ourselves into } \\
\text { teams and } \\
\text { tasked each } \\
\text { other to go } \\
\text { collec t the } \\
\text { necessary } \\
\text { community } \\
\text { challenges that } \\
\text { need to be } \\
\text { addressed. }\end{array}$ & $\begin{array}{l}\text { Yes, it was, because it } \\
\text { showed us that even } \\
\text { the least thought of } \\
\text { idea could be a } \\
\text { goldfield. }\end{array}$ \\
\hline 3 & $\begin{array}{l}\text { Not } \\
\text { necessar } \\
\text { y }\end{array}$ & $\begin{array}{l}\text { Surveyed the } \\
\text { need of the } \\
\text { community in } \\
\text { particular } \\
\text { students. }\end{array}$ & $\begin{array}{l}\text { Most definite, } \\
\text { communities have a lot } \\
\text { of challenges that could } \\
\text { be a hub for exercising } \\
\text { entrepreneurship and } \\
\text { innovation. }\end{array}$ \\
\hline 4 & $\begin{array}{l}\text { I don't } \\
\text { think so. }\end{array}$ & $\begin{array}{l}\text { We each came } \\
\text { up with ideas } \\
\text { from our } \\
\text { intuitive } \\
\text { processes and } \\
\text { from lecturers. }\end{array}$ & $\begin{array}{l}\text { Not necessary, we were } \\
\text { unsuccessful in almost } \\
\text { all the ideas. }\end{array}$ \\
\hline 5 & Yes & $\begin{array}{l}\text { We divided } \\
\text { ourselves into } \\
\text { focus areas; } \\
\text { then } \\
\text { interviewed } \\
\text { the community } \\
\text { of students } \\
\text { and people } \\
\text { from the areas } \\
\text { surrounding } \\
\text { the university. }\end{array}$ & $\begin{array}{l}\text { It was definite eyes } \\
\text { opening as indicated } \\
\text { that there exist a } \\
\text { plethora of ideas that } \\
\text { were entrepreneurship } \\
\text { and innovation. }\end{array}$ \\
\hline
\end{tabular}

entrepreneurship and innovation ideas derived from the different sources (see Figure $4 b$ ). It should be noted that the scope was expanded to include government, society, and industry. In this regard, students were introduced to the concept of Ideation (Idea generation) which is the beginning of an entrepreneurship and innovation process. Ideation (illustrated in Figure 5) is an interactive process that involves searching for the needs and problems in the student's environment and finding appropriate solutions or applying and developing known solutions (Thorsteinsson and Page, 2008; Malele, et al., 2017b). In this regard, feasible ideas that could be exploited for establishing a new venture are solicited from the Ideation process.
The EIE process is iterative with overlying direction,

but different steps in the process can be revisited as

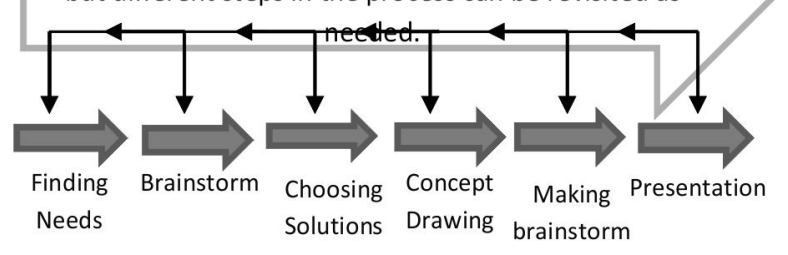

Figure 5: The Ideation process

(Source: Thorsteinsson and Page, 2008).

Figure 5 illustrate the steps which students were requested to complete as their entrepreneurship and innovation activity. Towards the end-of-the-semester students made oral presentations of their ideas and to protect students' intellectual property (IP), students presented their ideas at the instructor's office. Five points were used to assess students work and the results are discussed in the following section, Findings and Discussion.

The students' participation in this entrepreneurial and innovation activity was impressing. As a form of a feedback from students to the instructor (illustrated in Figure 6) a need for more time to conduct the assignment was identified. Others were only motivated to undertake their different tasks because of the need for module promotion not because they would like to become entrepreneurs and/or innovation actors as they did not highlight that their intention was to exploit their ideas into prototypes/products.

Figure 6 is supported by the extract below which represent the students' opinions after a framework was

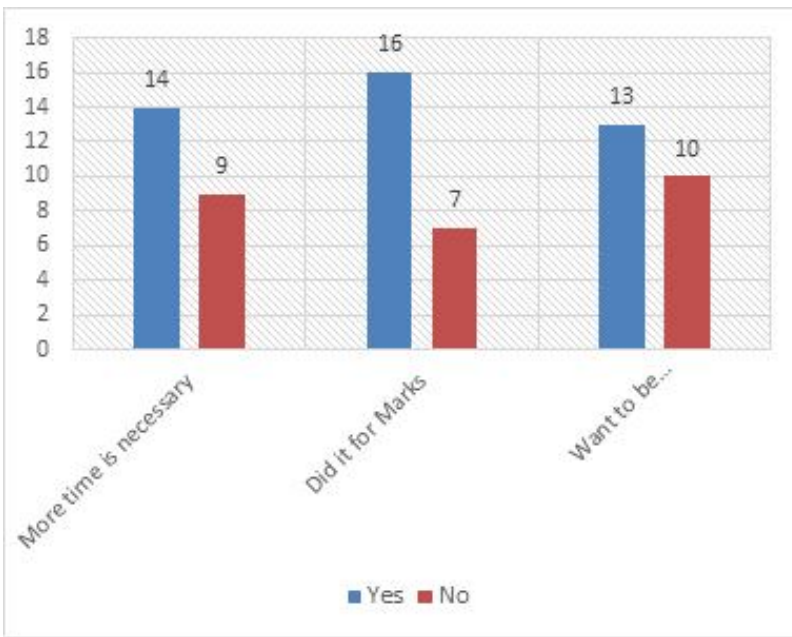

Fig. 6: Students' opinions after conducting the assignment. 
provided:

The instructor: "In relation to the aim of this assignment that of creating and increasing interest in establishing businesses, did the ideation framework help you to undertake your assignment? What was your motivation when you undertook the assignment?"

Group 1: "Indeed, the ideation framework helps to provide a guideline for the assignment but it did not allow us to think of exploiting our ideas into establishing businesses. In this regard, a much clearer framework with an emphasis on business establishment could help...Well despite module marks, we were interested to get exposure to how we can solve real problems. We feel more emphasis and practices should be done..."

Group 2: "the framework helped and we did the assignment for marks..."

Group 3: "first and foremost we did the assignment for obtaining passing marks and the framework helped..."

Group 4: "the assignment was eye-opening and the framework provided us with an opportunity of using the community problems and see if some are exploitable into business establishment..."

Group 5: "We feel that more marks are needed for this assignment, and there is a need for a framework that could allow us to work on our assignment but with a purpose of founding and developing organizations..."

In 2015, the USSBV process model (see Figure 7) was introduced to 20 students who formed four groups. The students were encouraged to use the USSBV model to undertake their NSY401T's entrepreneurship and innovation assignment that was similar to the previous years, i.e. "identification and suggestion of feasible wireless and mobile entrepreneurial and innovative ideas to solve the social and economic problems".

The only difference from previous years which were introduced by the USSBV was that beyond identifying feasible ideas and presenting them, they were supposed to conduct preliminary research (to identify possible market and technical consideration), develop necessary business documents and register their group as a company or business organization. The latter was introduced purposely, to allow students to have a knowhow of new venture legalities. For example, students could obtain a specific problem and specific ideas of a solution, then they would need to agree with that community on how they pursue coming up with a solution which among others, might include interviewing the community members under a specific royal chieftaincy. This would need some form of written ethical agreement.

The research and development for technical consideration on the feasible idea will be conducted; thereafter, the feasible idea will be developed as a prototype or product or service and be market or demonstrated to the potential market. The latter will be conducted under the auspices of a universitysponsored company.

Once student, understood the different stages of the USSBV, they created dummy companies and appointed group leaders as managing directors (MDs) then conducted their assignment under such auspices. Over-and-above oral presentations students submitted their reports in a business plan format to show how they could develop their ideas into businesses.

In 2015, students were requested to focus their wireless and mobile network ideas at addressing challenges from the different sectors because the USSBV could have the potential of leading them to establish businesses. In this regard, the majority of students selected ideas that have to do with software apps (as all the groups pointed out to that fact); this is supported by the following extract from the interviews:

The instructor: "What sector have you chosen for your assignment and why did you choose it?"

Group 1: "water is a challenge; it is a scarce commodity which should be monitored. Our entrepreneurship and innovation idea utilize wireless and mobile technology to communicate and create awareness to the house owner if that person has used water beyond the municipality level..."

Group 2: "these days everything is driven by software, hence a choice of a softwarebased solution in the form of apps for the 
online gym would be viable for the youth; because the youth spend most of their time on their mobile gadgets..."

Group 3: "Our idea is a solar-powered fan that could be activated using the phone. We choose the idea because of most people when they come back home from their office they want to find their home cool but they do not want to spend a lot on wall mounted fans. The phone would have a controlling app..."

Group 4: "our interest was to develop a voiceactivated door opening process which would also have a software app that recognizes the voice. In the future, this locking and opening technique could be applied to the gates and garage doors replacing the click of a remote. This would improve the house security..."

In 2016, the same briefing that was provided to the students in previous years was provided to a new group of 30 NSY401T students. However, the fully follow the USSBV model, the students requested to identify entrepreneurship and innovation funders, competitions and platforms where they could submit and present their ideas for funding that could aid them to further exploit their ideas into product/prototypes/service with some commercial value. The different organization were indeed identified and approached by students. However, students did not raise the university's Research and Innovation (R\&I) unit and Technology Transfer Office (TTO) as potential funders. Upon realizing that the students were not aware of their local setting, the instructor requested the students to be also cognizance of Innovation Competitions as one of the options for submitting their proposed entrepreneurship and innovation ideas/product/prototypes/service for prize-winning purposes.

During the presentations, in 2016, there were a number of ideas that the instructor felt that the students need to present to the university R\&I unit with a purpose of obtaining seed funding for developing them further. For example, one group developed a web-based physical science simulation software application (app) that could easily be accessed and operated through a smart mobile phone. The app used an innovative communication algorithm to foster collaboration among learners and their teachers.
The instructor assisted the students to develop technical drawings and flow charts which would illustrate their different simulation modules. Furthermore, the instructor linked the students with the university's TTO for the purpose of intellectual property (IP) registration and packaging the student app as a proprietary software.

As a follow-up, a future study aimed at evaluating the progress of such students and their challenges should be conducted. The latter will craft a research area that will further investigate students-tontrepreneurs/innovators chasm.

\section{Findings And Discussion}

In general, throughout the years (2013-2016) the students proposed good wireless and mobile networking ideas. Table XX summaries the students group scores on averaged using the following codes:

(i) $\mathrm{PI}=$ identification of a problem/challenge;

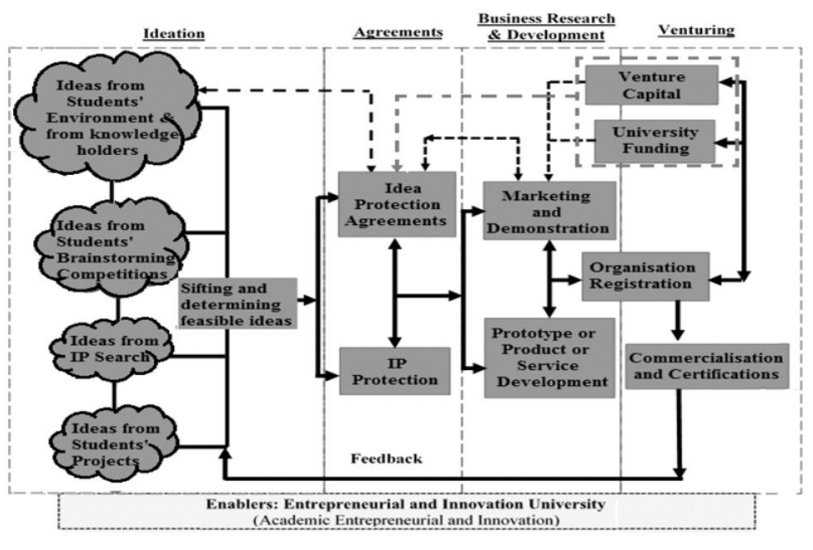

Fig.7: The University-Sponsored

Student Business Venture (Source: Malele, et al., 2017a)

(ii) $\mathrm{IPI}=$ information/knowledge on PI;

(iii)FIPI = at least five proposed ideas on solving the PI and choice of one feasible idea with a good motivation;

(iv) CIFIPI = creativity and innovativeness of possible ideas; and

(v) ACIFIPI = argument on presenting the assignment.

To further prop findings illustrated in Table 5, after each assessment year, a dichotomous 
questionnaire was disseminated to students with the aim of measuring students' interest on inclusion of the entrepreneurship and innovation activity in their ETE curriculum through assignments.

Table 5: Average scores on proposed entrepreneurship and innovation (throughout the years 2013-2016).

\begin{tabular}{|l|l|l|l|l|}
\hline & 2013 & 2014 & 2015 & 2016 \\
\hline PI & 56 & 62 & 65 & 77 \\
\hline IPI & 59 & 67 & 68 & 82 \\
\hline FIPI & 63 & 70 & 75 & 82 \\
\hline CIFIPI & 68 & 70 & 83 & 90 \\
\hline ACIFIPI & 70 & 78 & 70 & 91 \\
\hline
\end{tabular}

Majority of students were in agreement with such an inclusion because they believe it help them to: (i) develop an entrepreneurship and innovation culture and interest; (ii) understand the foundations of new venture development; and (iii) be motivated in pursuing business.

The latter is illustrated in Figure 8 and further corroborated by conducting a Pearson Correlation analysis using an online calculator (www.socscistatistics.com). The results of corroborating Figure 8 by conducting correlations to measure the strength between (i) interest vs understanding, (ii) interest vs motivation, and (iii) understanding vs motivation, are illustrated in Table 5 with a calculation for R-value and $\mathrm{p}$-value for interest vs understanding.

According to the results:

- Interest vs Understanding: the value of R is 0.7886 which indicates a strong correlation between the students' Interest and their Understanding of the entrepreneurship and innovation. The value for the coefficient of determination, R2 is 0.6219 meaning that $62 \%$ of the variance in Understanding scores is predictable from the Interest scores. The latter values were supported by the statistical significance at $\alpha=$ 0.05 of $p$-value $=0.020193$, meaning the Null hypothesis (there is no statistically significant relationship between students' Interest for- and their understanding of -entrepreneurship and innovation) is rejected, and the Alternative hypothesis (there is a statistically significant relationship between students' Interest for- and their understanding of -entrepreneurship and innovation) is accepted.

Interest vs Motivation: the value of $\mathrm{R}$ is 0.8738 which indicates a strong correlation between the students' Interest and their Motivation of the entrepreneurship and innovation. The value for the coefficient of determination, R2 is 0.7635 meaning that $76 \%$ of the variance in Motivation scores is predictable from the Interest scores. The latter values were supported by the statistical significance at $\alpha=$ 0.05 of $\mathrm{p}$-value $=0.04561$, meaning the Null hypothesis (there is no statistically significant relationship between students' Interest for- and their Motivation for -entrepreneurship and innovation) is rejected, and the Alternative hypothesis (there is a statistically significant relationship between students' Interest for- and their Motivation of -entrepreneurship and innovation) is accepted.

- Understanding and Motivation: the value of $\mathrm{R}$ is 0.9166 which indicates a strong correlation between the students' Understanding and their Motivation of the entrepreneurship and innovation. The value for the coefficient of determination, R2 is 0.8402 meaning that $84 \%$ of the variance in Motivation scores is predictable from the Understanding scores. The latter was supported by the statistical significance at $\alpha=$ 0.05 of p-value $=0.001361$, meaning the Null hypothesis (there is no statistically significant relationship between students' understanding of- and their Motivation for -entrepreneurship and innovation) is rejected, and the Alternative hypothesis (there is a statistically significant relationship between students' understanding of- and their Motivation for-entrepreneurship and innovation) is accepted.

Students' interest is proportional to their understanding and their motivation, vice-versa. Hence, students were in agreement with the inclusion of entrepreneurship and innovation as part of their studies. For example, throughout the years, 2013 2016, the students' interest in becoming an entrepreneur and/or innovation actor kept on increasing (see Figure 9). Figure 10, shows that the introduction of the guiding framework in the students' assignment was necessary and it helped in bringing the understanding of the entrepreneurship and innovation exercise.

Throughout the years, 2013 to 2016, majority of students have agreed sourcing entrepreneurship and innovation ideas were easier, while those ideas were in majority sourced from the communities (see Figure 11b). The students agreed that the entrepreneurship and innovation assignment was eye-opening. 


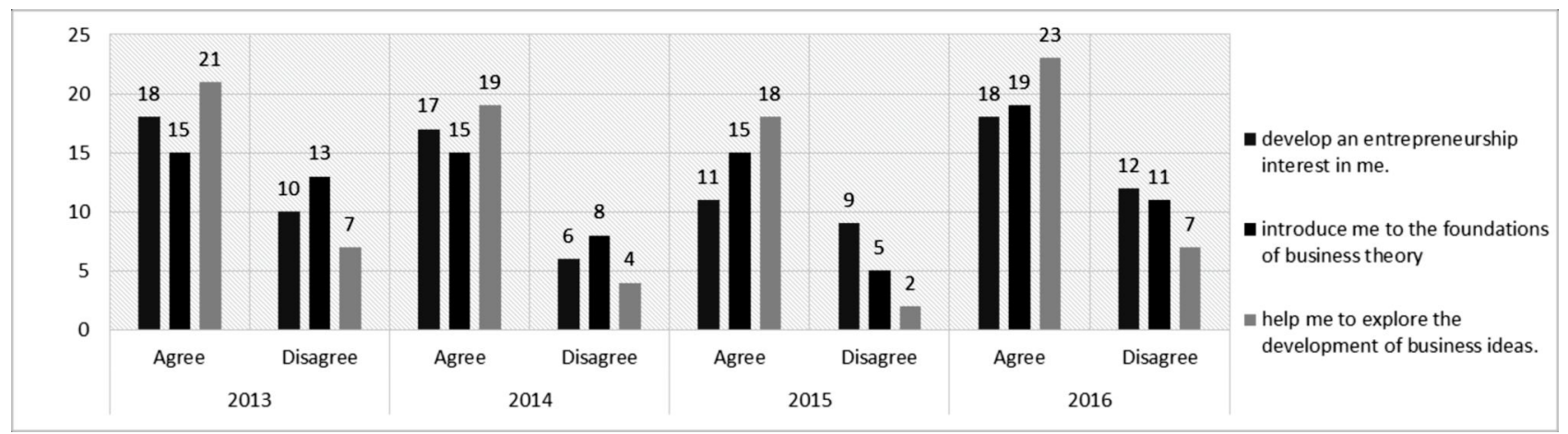

Fig. 8: Students interest in the inclusion of entrepreneurship and innovation

Table 5: Calculation for R-value and p-value for interest vs understanding.
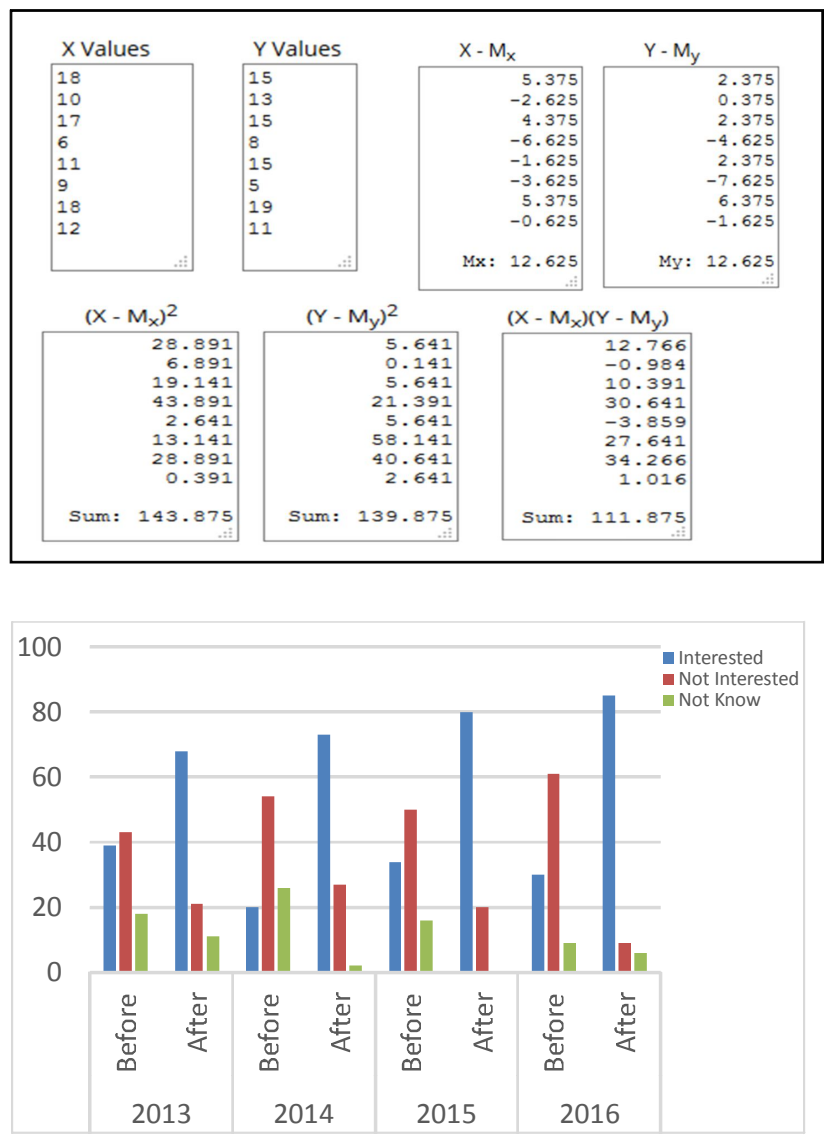

Fig. 9: Students' interest in becoming an entrepreneur and/or innovation actor (from 2013 to 2016).

\section{Conclusion}

In this paper, Generation $\mathrm{Z}$ was discussed and students ( 15 to 24 years of age) have been described as fitting the age profile of Generation $\mathrm{Z}$. In this regard, ETE students were viewed as potential entrepreneurship and innovation actors to whom EIE
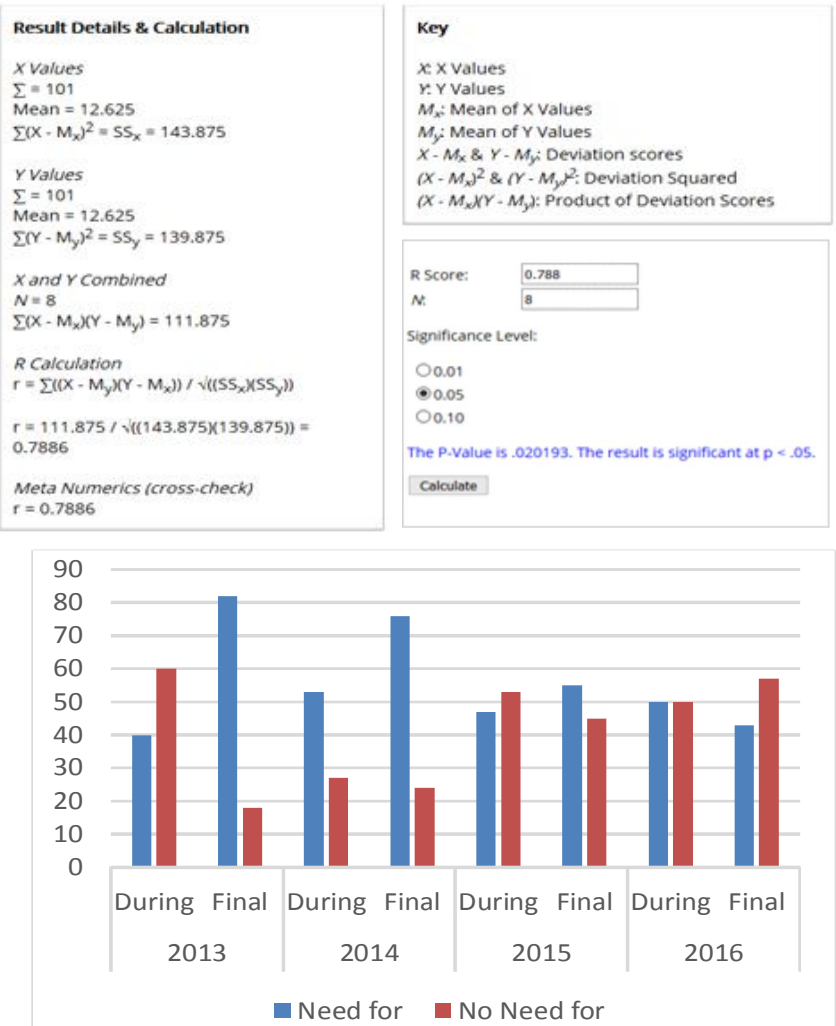

Fig. 10: Students' response to the need for the assignment guiding framework (from 2013 to 2016).

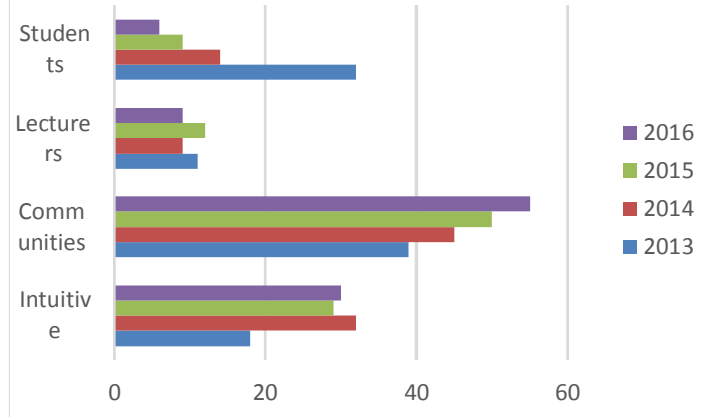

Fig. 11: Sources of entrepreneurship and innovation ideas. 
should be demystified. The latter was done by the inclusion of EIE activities in a mainstream ETE curriculum of the Network Systems at the university through the use of models such as the USSBV.

The use of the USSBV model as a guiding model to train students was a positive learning outcome. It increased the probability of ideas that could be exploited and provide the directions of how students could search for ideas or solutions that could address social and economic challenges; then see those ideas through a process that leads to an establishment of an organization. This was support by the 2016 example of a group of students that developed a web-based physical science simulation software with the aim of marketing it to the education sector. This idea was an intuitive one. In this regard, students could stand a chance to start and run their own businesses and be in a position of employing others. It should also be noted that funding seems to be a challenge for the exploitation of students' entrepreneurship and innovation ideas/products/services; hence, the university needs to be the initial funding source and assist students to legally register their own organizations as suggested by the USSBV.

The practice of entrepreneurship and innovation has the potential to lead to the establishment of new ventures. In this regard, future studies could focus on how an infusion of experiential training through product development and/or service delivery could be demystified by students and be presented at the university's business development units for the purpose of exploitation.

\section{References}

[1] Alzheimer-Europe. (2009) The four main approaches: Types of research, Available online: h t t p : / / w w w a $1 \mathrm{z}$ h e i m e r europe.org/Research/Understanding-dementiaresearch/Types-of-research/The-four-mainapproaches, (last accessed, 20 June 2015).

[2] ABET. (2018) The criteria for accrediting Engineering Technology Programs, ABET Board of Delegates, Available online: https://www.abet.org/engineering-technology2018-2019/(last accessed, 16 May 2019).

[3] Bahill. A.T. and Gissing, B. (1998) Re-evaluation Systems Engineering Concepts Using System Thinking, IEEE Transactions on Systems, Man, and Cybernetics, Part C (Applications and $\mathrm{R}$ e vi e w s ) 28 ( 4 ). http://ieeexplore.ieee.org/document/725338.

[4] Carew, A.L. and Cooper, P. (2008) Engineering Curriculum review: processes, frameworks, and tools. in 'Quality Assessment Employability and Innovation', F.K. Fink (eds.), the 36th Société Européenne pour la Formation des Ingénieurs/European Society for Engineering Education (SEFI) Annual Conference 2008 proceedings, Aalborg, Denmark, July, 2-5, 2008.

[5] Creswell, J.W. (2014) Research Design: Qualitative, Quantitative and Mixed Methods Approaches. USA: Sage Publications.

[6] Cristina, M.D. (2016) Promoting Technological Entrepreneurship through Sustainable Engineering Education, Procedia Technology 22: $1129-1134$.

[7] Enikő, S.M. (2013) Didactic Teaching strategies for successful learning, PedActa 3(2), 51-58.

[8] Fernández-Cruz, F.J. and Fernández-Díaz, M.J. (2016) Generation Z's Teachers and their Digital Skills, Media Education Journal, Comunicar XXIV(46), 97-105.

[9] Geck, C. (2007) The Generation Z Connection: Teaching Information Literacy to the Newest Net Generation, in E. Rosenfeld, D.V. Loertscher (eds.), Toward a 21st-Century School Library Media Program, pp. 235-241, USA: Scarecrow Press.

[10] Glasgow, R.E. (2013) What Does It Mean to Be Pragmatic? Pragmatic Methods, Measures, and Models to Facilitate Research Translation. Health Education \& Behavior 40(3): 257-265.

[11] International Labour Organisation (ILO). (2008) Report V: Skills for improved productivity, employment growth and development, 97th Session of the International Labour Conference 2008 proceedings, Geneva, Switzerland. April $15,2008$.

[12] Malele, V., Mpofu, K., and Muchie, M. (2016) Bridging the Innovation Chasm: Computer Systems Engineering students' attitude, biasness and perception towards entrepreneurship and 
innovation, in W. Mwakapenda, T. Sedumedi \& M. Makgato (eds.), the 25th Annual Conference of the Southern African Association for Research in Mathematics, Science and Technology Education 2016 proceedings, Tshwane University of Technology, Arts Campus, Pretoria, South Africa., January 12-15, 2016.

[13] Malele, V., Mpofu, K., and Muchie, M. (2017a) University Sponsored Students Business Venture Model for Bridging the Entrepreneurial and innovation Chasm, the 1st International Conference on Entrepreneurship Development (ICED) 2017 proceedings, Central University of Technology, Bloemfontein, South Africa., April 5-7, 2017.

[14] Malele, V., Mpofu, K., \& Muchie, M. (2017b) Lesson learned from exposing Computer Systems Engineering students to entrepreneurship and innovation activities, in B. Collier-Reed, (eds.), the 4th Biennial Conference of the South African Society for Engineering Education (SASEE) 2017 proceedings, Cape Town Lodge, Buitengracht Street, Cape Town., June 14-15, 2017.

[15] Morgan, D.L. (2013) Integrating qualitative and quantitative methods: A Pragmatic Approach, Thousand Oaks: Sage Publication.

[16] Okudan, G.E., and Rzasa, S.E. (2006) A projectbased approach to entrepreneurial leadership education, Technovation 26, 195-210.

[17] Rozenberga, G., and Paidere, I. (2015) Gen Z vs Academic Libraries. An Academic Library of Generation Z: Services, Spaces, and Technologies 2015 proceedings, viewed 24 June 2017 , $\mathrm{f} \mathrm{r}$ o $\mathrm{m}$ https://biblioteka.vu.lt/files/naujienos/bylos/14. $\begin{array}{cccccccccccccc} & \mathrm{g} & \cdot & \mathrm{r} & \mathrm{o} & \mathrm{z} & \mathrm{e} & \mathrm{n} & \mathrm{b} & \mathrm{e} & \mathrm{r} & \mathrm{g} & \mathrm{a} & \text { - }\end{array}$ i.paidere_z_karta_pries_akademines_biblioteka s_paslaugu_prieinamumas.pdf

[18] Schroer, W.J. (2008) Generations X, Y, Z and the Others. The Journal of the Household Goods Forwarders Association of America XL, viewed 10 March 2017, from: http://iam.files.cmsplus.com/newimages/portalpdfs/2008_03_04.p df

[19] Schunn, C.D., and Silk, E.M. (2011) Learning theories for engineering and technology education, in M. Barak \& M. Hacker (eds.), Fostering Human Development through Engineering and Technology Education, pp. 318, Rotterdam: Sense Publishers.

[20] Soares, F.O., Sepúlveda, M.J., Monteiro, S., Lima, R.M., and Dinis-Carvalho, J. (2013) An integrated project of entrepreneurship and innovation in engineering education, Mechatronics 23(8), 987-996.

[21] Statistics South Africa (Stats-SA). (2019) Quarterly Labour Force Survey: Quarter 1, Statistical Release P0211. Statistics South Africa, Pretoria.

[22] Teddlie, C. and Tashakkori, A. (2009) Foundations of Mixed Methods Research: Integrating Quantitative and Qualitative Approaches in the Social and Behavioral Sciences. London: Sage Publications.

[23] The Entrepreneur Africa Magazine. (2017) Key difference-Innovation vs Entrepreneurship. The Entrepreneur Africa Magazine, viewed 20 March 2017 , f $\mathrm{r}$ o $\mathrm{m}$ : http://www.theentrepreneurafrica.com

[24] Thorsteinsson, G. and Page, T. (2008) A Virtual Reality Learning Environment to improve Ideation: An Icelandic Action Research Project. Pedagogika 91.

[25] Timmons, J.A., Zacharakis, A, and Spinelli, S. (2004) Business Plans that work: A Guide for Small Business, New York: McGraw Hill.

[25] UNESCO. (2010) Engineering: issues, challenges and opportunities for development, United Nations Educational, Scientific and Cultural Organization, France: Paris.

[26] Van der Lingen, E. and Van Niekerk, G. (2015) Entrepreneurship Traits of Science, Engineering and Technology (SET) Students, The Southern African Journal of Entrepreneurship and Small Business Management 7.

[27] Venturewell. (2016) 5 Trends that will shape Entrepreneurship Education in 2016 , Venture we $11, \quad$ A vail a ble online:http://www.venturewell.org/5-Trends- 
that-will-shape-Entrepreneurship-Education-in2016 (last accessed: 20 March 2017).

[28] Wilson, M.D., Holloway, E., Cox, M. and Goldstein, M. (2014) Entrepreneurship
Education: Engineering a Pracademic Approach, the American Society for Engineering Education (ASEE) 2014 proceedings, North Midwest Section Conference, Iowa City, IA, October 16-17, 2014. 